\title{
Spirituality and Strategic Leadership: The Leaders' Perspective
}

\author{
Pallavi Thacker $^{1}$ and H. P. Mathur ${ }^{2}$
}

\begin{abstract}
The purpose of this paper is to figure out the role of spirituality in strategic leadership. Strategic leadership has much to do with the organizational performance; and spirituality as an ingredient to the strategic leadership affects it to a great extent. This paper focuses on how the personal spiritual beliefs of a top leader shape the decisions and thus the organizational performance. The paper also proposes that spirituality must be studied as an ingredient of psy chological make-up of a leader.

Review of the existing literature in the fields of strategic leadership and spirituality has been done. Documentary data from the secondary sources such as newspapers, magazines, websites and autobiographies has been collected and discussed so as to know what business leaders think of spirituality.

The paper concludes with the finding that satisfaction of self is what most of the business leaders mean by the term "spirituality".
\end{abstract}

Keywords - Spirituality. Strategic Leadership. Organizational Performance. Business leaders.

\section{INTRODUCTION}

A question of key importance in predicting organizational success is what factors determine its performance. There have been two views typically, when we try to study organizational performance through strategic processes. One view holds that when strategic "process" is studied, it is viewed as flows of information and decisions, detached from the people involved (Aguilar, 1967; Allen, 1979; Bowgeois, 1980; Mintzberg, Raisinghani \& Theorot, 1976). Another view advocates that organizational outcomes strategic choices and performance levels - are partially predicted by managerial background characteristics (Hambrick \& Mason, 1984). This has to say that top executives matter. We take this view into account as we discuss the concept

ahead. Leadership plays a vital role in determining the organizational performance. Leadership again, has many dimensions. Leadership in organizations is typically and technically termed as Supervis ory Leadership; while leadership of organizations is known as Strategic Leadership.

\footnotetext{
${ }^{1}$ Research Scholar, Institute of Management Studies, Banaras Hindu University, Varanasi.pallavithacker@yahoo.com.

${ }^{2}$ Professor, Institute of Management Studies, Banaras Hindu University, Varanasi. hpmathur@yahoo.com.
}

Strategic Leadership focuses on the people who have overall responsibility for the organization and includes not only the titular head of the organization, but also members of what is referred to as the top management team or dominant coalition (Cyert \& March, 1963). The managerial background characteristics that Hambrick \& Mason talk about involve the psychological make-up, family background, upbringing, social surroundings, education, work experience and the contemporary things that shape up an individual's mind. Environmental complexity, organizational structural complexity, demographic factors etc. Also play a vital role. When we talk of the psychological make-up of a leader, or as a matter of fact, any individual, spirituality also forms a part, and many a time, the most prominent part.

When Facebook was going through tough times, Steve Jobs (Founder of Apple Inc.) advised Mark Zuckerberg (Chairman, Chief Executive, and Co-Founder of the social networking website Facebook) to make a spiritual pilgrimage to India. Mark spoke during a stage appearance.

"This is a story I haven't told publicly, and very few people know. Early on in our history,

before things were really going well, we hit a tough patch and a lot of people wanted to buy Facebook, and thought we should sell the company. I went and saw one of my mentors, Steve Jobs, and he told me that in order to reconnect with what I thought was the mission of the company, I should visit this temple that he has gone to in India early on his evolution of thinking about what he wanted Apple and his vision of the future to be."

This was probably the leader's spiritual quotient that came into the picture. Had not Mark worked on the advice of Steve Jobs, what were the possible consequences Facebook would have gone through? May be it survived; may be it failed. But Mark owes this survival and well-being to Steve's advice. Evidently, spirituality guides the actions of top executives. If not in all cases, in some cases it certainly does. When does it matter and to what extent, this needs to be explored.

A search on Google Scholar, Emerald Insight and other data banks displayed very few research articles explicitly talking of the relationship between Strategic Leadership and Spirituality. Here arises a question that what has kept authors away from writing in this connection, and why the related literature is not so enriched? 
Strategic leadership is a well-developed field and it has tried to explore well all the issues at details, but the element of spirituality as an element of psychological make-up of a leader still remains unexplored. It is thus important to reach out to the documentary data available where it can be found what leaders have to say about spirituality and what forms of spirituality they practice, if at all they do. This being our first work towards addressing spirituality and strategic leadership, the available documentary data will be explored and discussed. We intend to bring out very soon, next part of it, where viewpoints of operating business leaders will be taken into consideration by interviewing them.

This research paper may make the following contributions:

i. Connecting the two very well established and well researched concepts, strategic leadership and spirituality; and thus adding to the existing pool of literature.

ii. Paving the way for suggesting the suitable approaches towards spirituality in the form of theories / programmes / sessions to business leaders.

iii. Succession planning being one of the major issues (especially in Indian firms) may be facilitated if a suitable and practical connection between spirituality and strategic leadership is derived.

iv. Opening the path for further research in this area for academicians and scholars for the purpose of generalization of findings.

\section{STRATEGIC LEADERSHIP AND SPIRITUALITY: CONCEPTS AND CONNECTION}

Strategic leadership is the leadership of and for the new types of relationships that are emerging in the knowledgebased economy (Gibney, Copeland and Murie, 2009). It is a form of leadership that seeks to generate, renew and sustain the collective learning cycle.

At strategic level, leadership is the key issue facing organizations in the 21st century (Ireland \& Hitt, 2005). Without effective strategic leadership, a company's ability to achieve and sustain a competitive advantage is greatly constrained. The conceptualization of leadership at strategic level should be based on the notion that the relational components of leadership constitute the core of strategic leadership. Furthermore, the members of TMTs should be considered the key participants in the strategic leadership process, which conceivably could influence innovation processes at organizational level (Elenkov, 2005). The scope of Strategic Leadership is broad. The strategy is the plan, while strategic leadership is the thinking and decision making required to develop and affect the plan. Supervisory leadership is about leaders "in" organisations, whereas strategic leadership is concerned with leadership "of" organis ations (Boal \& Hooijberg, 2000).

It is all about people who give guidance and directions. For any company, intelligent guidance requires a clear sense of purpose, of what makes the organization truly distinctive.
(Montgomery, 2008) Purpose, Montgomery says, serves as both a constraint on activity and a guide to behaviour. Creativity and insight are key to forging a compelling organizational purpose; analysis alone will never suffice. As the CEO--properly a company's chief strategist-

-translates purpose into practice, he or she must remain open to the possibility that the purpose itself may need to change.

There have been many theoretical perspectives to Strategic Leadership. One very renowned and accepted is the Upper echelons theory.

\section{THE UPPER ECHELONS PERSPECTIVE}

Rooted in Cyert \& March's (1963) behavioural theory of the firm, the Upper Echelons perspective (Hambrick \& Mason, 1984) implies that organizational decisions are not reflections of rational choices, but are rather results of top managers" "cognitive maps"

through which different problems are viewed and interpreted (Dutton, Fahley \& Narayanan,

1983: 310). Like other social aggregates, executive teams make decisions based on their members' cognitive frames and past experiences - as they "construct, rearrange, single out, and demolish many 'objective' features of their surroundings" (Weick, 1979: 164). Thus, assessing the impact of top managers on organizations is a worthwhile research endeavour (Boone et al., 2004; Hambrick, 2007).

Hambrick \& Mason (1984) illustrate a process through which top managers make strategic choices that eventually impact firm performance.

Fig.1: The upper echelons pers pective

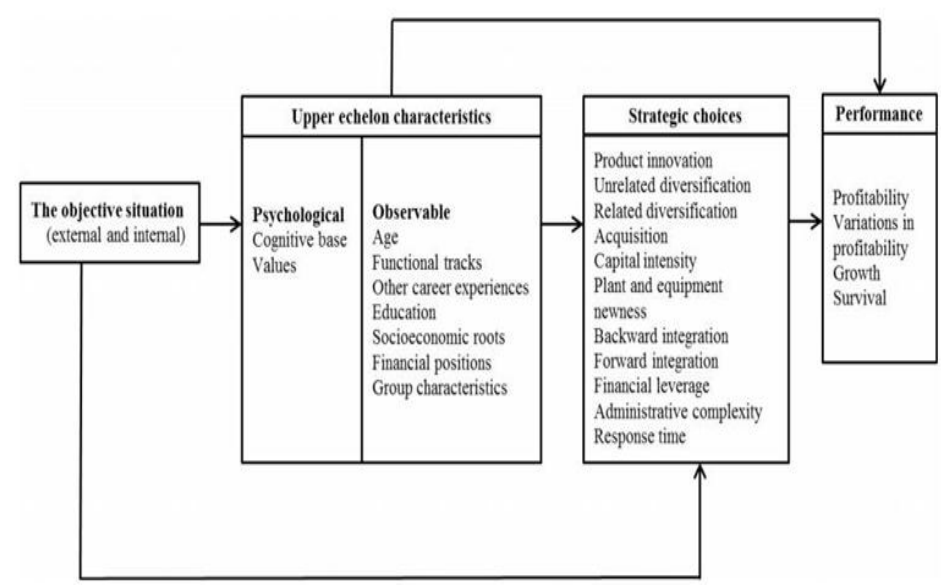

Source: Hambrick \& Mason, (1984: 198)

The authors claim that leaders' decisions are shaped through their psychological attributes and observable demographic characteristics, such as their age, gender, nationality and experience. Psychological attributes take into account. Since individuals' psychological characteristics are difficult to measure and quantify, executives' demographics can be used as substitutes for examining their values, beliefs and cognitions (Hambrick \& Mason, 1984).

A run-through from this perspective and similar perspectives on the leader's behavior and actions rarely find 
the discussion of spirituality; may be because defining and understanding spirituality seems complex.

Spirituality is about "spirit". Spirit may be called as the deeper sense, meaning or significance of something. The term spirituality has experienced changes in its connotation several times throughout history. These changes reflected the political, social, philosophical, and religious aspects of specific periods in time, and in the development of humanity. The Latin for spirituality, spiritualitas is an abstract noun like the words beauty or honesty and was derived from the noun spiritus and the adjective spiritualis (Farina, 1989). In Latin translations of letters written by followers of the Catholic Pauline tradition, these words were used to describe the opposition of two ways of life. One way, the way of spirituality, was the way of life in which the person was led, ordered, or influenced by the Spirit of God. The other way of life was described as "all that is opposed to the Spirit of God" (Sheldrake, 1991, p. 43). In this early usage of the term spirituality, a spiritual person was not someone who turned away from material reality but rather someone in whom the Spirit of God dwelled...and acted as to advance in spirituality (Sheldrake, 1991 p.43). Times changed, and notions changed.

For the purpose of this paper, we would talk also about the "organizational spirituality". While some authors treat spirituality as an individual phenomenon (Ashforth and Pratt 2003), some describe it as an organizational dynamic (Mitroff and Denton 1999). Some authors have asserted that "...every entity, individual or group, has a spirit" (Marques et al. 2005). Spirituality sometimes talks of an individual as a whole and asks for no spaces for other entities to exist, such as organizations; and sometimes, spirituality of workplaces, i.e., organizations is talked of where individuals form a part of the whole.

A number of research studies have been directed at defining spirituality and its relationship with transformational leadership in secular settings. In 1994, respondents in Dr. Stephen Jacobsen's study provided many diverse meanings for spirituality including: a relationship with a transcendent power; a guide for personal values and meaning making; a way of understanding the world; an inner awareness; and a means of personal integration. Hahn D'Errico's 1998 study found that study participants, organizational development consultants defined spirituality "in terms of universal principles such as unity, interconnectedness, love, compassion, energy and intuition". In another study examining transcendence in the organization, Lund Dean (2002) defined spirituality in terms of "employee experiences at work that surpass everyday meaning by facilitating some fulfilling relationship with a higher power or transcendent being" (Lund Dean, 2002).

Vail (1996) describes spirituality as a decision to open one' self to a transcendent source of meaning. Learning then becomes a way of being; a life-long journey and search for meaning and purpose. The scholar and educator, Parker Palmer (1993) in his essay Leading from Within described spirituality as the leader's power to create the conditions under which other individuals or groups must live and move and have their being. A leader is a person who must take special responsibility for what is going on inside him or her-self, inside his or her consciousness, lest the act of leadership create more harm than good (p. 7). Fairholm (1998) stated that spirituality in the corporation referred to the inner values of the leader and the followers -the mature principles, qualities, and influences that people implicitly exhibited in behaviour and interactions with others. Thus, the integration of the many components of one's work and personal life into a comprehensive system for managing the workplace defined the holistic or spiritual (whole person) leadership approach.

As the connotation of spirituality has differed from time to time and context to context, its meaning also differs from person to person. While reviewing the documented data, it was found that the meaning of spirituality differed among business leaders.

\section{VIEWS OF BUSINESS LEADERS ON SPIRITUALITY}

For Robert Glassman, his spirituality at work was expressed as a commitment to social justice. As co-founder and cochairman of Wainwright Bank \& Trust Company based in Boston, Glassman said issues such as homelessness, women's rights and outreach to the gay and lesbian community have shaped his own life and the life of his business.

According to Ricardo Levy, chairman of Catalytica Energy Systems, executives are trained for action-contemplation is not part of their rulebook. In his own career, however, he discovered the need for spiritual guidance in crucial decisions, especially those that affect other people such as employees, he said. Levy's guidelines are:

Quiet the mind. Reach deep inside. Go beyond the ego to hear the inner voice.

Don't fear ambiguity; rest in the unknown. "This is the most difficult piece," Levy admitted. "We're not comfortable unless we see the path."

Stay humble in the face of temptation and power. "Being humble is a key issue. It's good for a leader to be reminded of the intoxication of power."

Asked by a member of the audience for his definition of success, Levy said,

"I'd rather use the word fulfilment. Success is a metric; you never have enough. But only you can define fulfilment. We as individuals are the only judges." 1

Two CEOs of different faiths, Christian and Muslim, discussed how their spirituality helped them evolve as leaders.

"There are so many pressures on you as a leader to lose your compassion and develop a thick skin, to lose your capacity for doubt and curiosity," said Dr. Ronald Heifetz, founding director of the Centre of Public Leadership at Harvard University's John F. Kennedy School of Government, who moderated the discussion. He invited the panellists to discuss how they have the courage to maintain their openness when so many people around them look to them to be answer machines, rather than evolving creatures.

"I am a follower of Jesus Christ," began C. William Pollard, Chairman of The ServiceMaster Company, based in Chicago, Illinois. In order to lead his company in the right way, he often asks himself these questions: Who are people and why do 
they work? How does the community of work affect the person I'm becoming? How can we better address the spiritual side of a person and be faith-friendly and diverse? How are we treating people? Are we dealing with the whole person?

In a service industry, where most jobs can be described as "menial" and entry-level, he retains employees and maintains morale by embodying his belief that "every person is created in God's image and deserves dignity in their work." To this end, every single person at the company is required to spend at least one day a year providing their services in the field.

Steve Jobs, Apple's founder, has his own meaning of spirituality. "I believe life is an intelligent thing, that things aren't random," Jobs said in a 1997 interview with Time, providing a glimpse into his complicated belief system that extends well beyond the Buddhist teachings.

${ }^{1}$ (Lagace, Silverthorne \& Guild, 2002)

Karma is another principle of the religion, but it didn't appear to be a system Jobs lived by. If he feared karma coming back to bite him, the sentiment wasn't evident in his public statements about competitors and former colleagues, calling them "bozos" lacking taste. Those who worked for Jobs described him as a tyrant they feared meeting in an elevator.

Jobs always said that "we're here to put a dent in the universe" and this he wished to achieve in his own special way. No philanthropy, not much of richness, but through providing customers with something different; not just a product, but an experience. He designed all the systems accordingly, and those systems provided him satisfaction. This was spirituality for him. (Milian, 2011)

Mr. Kamalnayan Bajaj's elder son, Mr. Rahul Bajaj is the head of the Bajaj Group. In an interview with Times of India, in the year 2006, Rahul says,

"Spirituality, to me, is trying to connect with the beyond. Faith in spirituality helps me lead a good life - a life of integrity, a life without any bias. We all believe in God because fear of God keeps us on the right path. Even if there is no God, just the belief that there is something beyond our understanding that takes care of our life can take us a long way. In my 40 years in management, I have always had faith in the theory of Maslow's Hierarchy of Needs. The theory contends that when humans meet the basic needs, they seek to satisfy successively the higher needs that occupy a set hierarchy. We then strive to be the best we can be, which leads to self-actualisation. And, this is what spirituality is all about - going beyond your needs. I believe in karma-one is responsible for one's own life. By sincere tapasya, you can achieve everything you want. I am very religious, but I don't believe in formalities. I don't go to temples often. Last time I went was five years back, to a temple constructed by my grandfather in our village. I always try to be happy. My work is my joy. Meeting different people in the course of my work gives me immense happiness.You should do what you really enjoy doing. And, you should be the best in whatever you do."

Other business leaders Ajay Piramal (Chairman, Piramal Group, India) and Kishore Biyani (Founder and Chief Executive Officer of Future Group, India) at a seminar organised by the
Confederation of Indian Industry (CII), said that spiritual principles are universal and can be used as beacons for illuminating the complex and intriguing world of business. While Biyani had only recently discovered spirituality, Piramal said that spiritual values can create even economic value giving the example of Mahatma Gandhi's successful career as a lawyer in South Africa. (Ashish Virmani, 2014)

${ }^{2}$ (Shanthi, 2006)

Shivinder Mohan Singh, one of the two founders of Fortis Healthcare, will give up his executive role at the owner of the hospital chain and join the Radha Soami Satsang Beas (RSSB), a spiritual movement that has a large following in northern India. (adopted from an article from The Hindu, September 2015) Shivinder said he wants to dedicate rest of his life in social uplift of the downtrodden; and he believes he will get closer to spirituality by doing this. (Kumar, 2015)

Serco Global Services' Chief Marketing Officer Sandeep Aggarwal prefers to delve into the past to get closer to self and spirituality. This past life regression practitioner says looking into the past can become a way to find happiness and understand why one is going through difficult times. "Self regression is gym for the soul. It can lead to catharsis and for many it is an alternative to visiting a psychiatrist or psychologist," says Aggarwal. His belief in religion and spirituality piqued his interest in Brian Weiss's book Many Lives Many Masters. Aggarwal practices meditation as is a great believer of the existence of spirit and God. (Sengupta, 2014)

There are many more examples from the business world where business leaders mention the term spirituality and define it in their own different ways; but somehow those remain unattended. The need for the hour is to take into consideration the element of spirituality in the psychological make-up of business leaders.

\section{THE NEED TO INTEGRATE SPIRITUALITY WITH STRATEGIC LEADERSHIP}

Leadership is a managerial concept that focuses entirely on the human aspect. Now how a human being behaves/ acts in a certain situation depends upon her/his psychological make-up and the surroundings in which (s)he is operating as a leader. Surroundings such as organizational structure, organizational complexity, political and social environments, almost all have been studied deeply and relevant concepts and theories have been devised that answer what style of leadership hold suitable in which situation. But when discussing the psychological make-up, values, attributes, rationality, entrepreneurial spirit and demographic factors come into the picture; but the spiritual quotient of the mind remains unexplored. Spirituality is as important as any other component that shapes up the psychological frame of mind. Especially in a country like India which is known for its values of religion and spirituality. There have been into existence many forms of spirituality. While discussing forms, there can be many as quoted by different authors and practitioners; religious spirituality, non-religious spirituality, spirituality of ordinary life, kindness, creative transformation, awakening to divine 
archetypes, serving humanity, prophetic spirituality, and the list goes on. Generally when we think of this concept, an entirely different field of spirituality comes to our minds; but reality says that spirituality exists in our daily lives, in whatever that makes our hearts feel glad, in whatever that brings us happiness. Success may be spirituality, kindness may be spirituality. Business leaders discussed here have their own opinions based on their beliefs and experiences.

Not only India but entire world is now trying to get closer to spirituality; for instance, Yoga, as a medium towards self improvement and spirituality has gained a global identity. The world celebrated June 21, 2015 as the first International Yoga Day. Never before yoga has been accepted and appreciated on such a large platform. May be because of the changing lifestyles, or because it is the need of the hour get back to our roots, spirituality is much talked about.

We have also come across examples where business leaders from outside India show the spiritual inclination; and this inclination has resulted in better organizational performance. It thus becomes important to know the "what" "when" and "how" of spiritual beliefs of leaders.

Their lies another important aspect on the part of the followers. "Good followers make great leaders" is not just a saying but a reality. Like-minded people can work together in a better way. Similarly, a follower with a spiritual inclination may deliver better in an organization where spirituality lies in its roots in the form of its leadership.

Thus, an understanding of spirituality in connection with strategic leadership may prove to be a two-way benefit.

\section{CONCLUDING REMARKS}

Spirituality is something that is embedded deeply in the roots of Indian culture. It is all about the invisible power prevailing in the universe that controls everything. It is all about spirit; the deeper sense, meaning or significance of something. Apparently, it has to be everywhere; including all individuals (with varying extents) at all levels. This paper tries to find a connection between spirituality and strategic leadership through available literature, and also to find out what business leaders think about spirituality. Going through the statements given by business leaders, some particular traits can be figured out which meant being spiritual to them. The traits are:

- Having concern for social is sues

- Being humble to others

- Having a sense of compassion

- Having emotional concern for people working under them

- Having faith in God

- Holding a belief in Karma

- Practicing meditation

- Seeking satisfaction in whatever they do

Among these traits, seeking satisfaction from work has been mentioned the most.

It can be tentatively said that these traits in a strategic leader make her/him spiritual. There may be many more traits as we go further deep into the available talks with leaders. Also, interviewing operating business leaders will add to the list of traits, and the common traits that are mentioned the most may take this type of a research into generalization.

This approach towards spirituality and strategic leadership highlights opportunities for research and integration yet to be explored in the existing literature.

Leadership exists in different level in organizations. Also, spirituality follows a hierarchy. After finding out the common traits of spirituality among business leaders, a continuum may be developed so as to see if any kind of relationship between the respective hierarchies of spirituality and leadership exists.

Organizations now-a-days are organizing programmes and camps in order to promote spirituality among their employees; the effectiveness of those can also be measured by developing such a continue.

\section{REFERENCES}

[1] Ashish Virmani (2014). When spirituality met business. Retrieved from http://www.dnaindia.com/mumbai/report-when-spiritualitymet-business-2043508

[2] Ashforth, B. E., \& Pratt, M. G. (2003). Institutionalized spirituality: An oxymoron? In R. A. Giacalone \& C. L. Jurkiewicz (Eds.), Handbook of workplace spirituality and organizational performance (pp. 93-107). Armonk, NY: M. E. Sharpe.

[3] Boal, K., \& Hooijberg, R. (2000). Strategic leadership research: moving on. The

[4] Leadership Quarterly, 11(4), 515-549. https://doi.org/10.1016/S1048-9843(00)00057-6

[5] Devina Sengupta (2014) Past life regression helps you understand present better \& find happiness in future:Sandeep Aggarwal, CMO, Serco. $\quad$ Retreived from http://economictimes.indiatimes.com/magazines/panache/past -liferegression-helps-you- understand-present-better-find-happiness-infuturesandeep-aggarwal-cmo- serco/articleshow/33810634.cms

[6] https://doi.org/10.1002/smj.469 https://doi.org/10.1002/smj.469

[7] Fairholm, G. W. (1998). Perspectives on leadership: From the science of management to its spiritual heart. Westport, Connecticut: Praeger Publishers.

[8] Farina, J. (1989). The study of spirituality: Some problems and opportunities. U. S. Catholic Historian 8(1-2): 15-31.

[9] Gibney, J., S. Copeland and A. Murie (2009) Toward a 'new' strategic leadership of

[10] place for the knowledge based economy. Leadership, 5: 5-23. https://doi.org/10.1177/1742715008098307

[11] Georgopoulos, B., Tannenbaum, A. (1957), “A Study of Organizational

[12] Effectiveness", American Sociological Review 22, pp. 534-40

[13] https://doi.org/10.5465/AMR.1984.4277628https://doi.org/10.546 5/AMR.1984.4277628 https://doi.org/10.5465/AMR.1984.4277628

[14] https://doi.org/10.5465/AME.2005.19417908 https://doi.org/10.5465/AME.2005.19417908

[15] Kaplan, R.S., Norton, D.P. (1993), "Putting the Balanced Scorecard to Work",

[16] Harvard Business Review, September-October, pp. 134-147

[17] Kumar Arun (2015). Fortis Healthcare cofounder Shivinder Mohan Singh set to join spiritual movement Radha Soami Satsang Beas. Retrieved from http://articles.economictimes.indiatimes.com/201509-23/news/66822665_1_shivinder-singhfortis-healthcarebhavdeep-singh 18 
[18] Lebans, M., Euske, K. (2006), "A conceptual and operational delineation of performance", Business Performance Measurement, Cambridge University Press

[19] Luke Dormehl (2015) Steve Jobs told Mark Zuckerberg to make a spiritual pilgrimage to India. Retrieved from http://www.cultofmac.com/390447/steve-jobs-told-mark-

[20] zuckerberg-to-make-a-spiritual-pilgrimage-to-india/

[21] Lund Dean, D. K. (2002). Religion, spirituality, and work: Transcendence in the organization. Unpublished doctoral dissertation, Saint Louis University.

[22] Lusthaus, C., Adrien, M.-H. (1998), “Organizational assessment: A review of experience", Universalia, 31

[23] Martha Lagace, Sean Silverthorne \& Wendy Guild (2002) Does Spirituality Drives

[24] Success. Retrieved from http://hbswk.hbs.edu/item/does-spiritualitydrive-success

[25] Marques, J., Dhiman, S., \& King, R. (2005). Spirituality in the workplace: Developing an integral model and a comprehensive definition.The Journal of American Academy of Business, Cambridge, 7, 81-91.

[26] Mark Milian (2011). The Spiritual side of Steve Jobs. Retrieved from http://edition.cnn.com/2011/10/05/tech/innovation/stevejobs-philosophy/

[27] Mitroff, I. I., \& Denton, E. A. (1999). A spiritual audit of corporate America: A hard look at spirituality, religion, and values in the workplace. San Francisco: Jossey-Bass.

[28] Palmer, P. (1993). Leading from within.Washington D.C.: Servant Leadership Press.

[29] Shanthi (2006). I M: Rahul Bajaj. Retrieved from http://timesofindia.indiatimes.com/life style/I-AM-RahulBajaj/articleshow/1717419.cms

[30] Sheldrake, P., SJ (1991). Spirituality \& history: Questions of interpretation and method. Maryknoll, New York: Orbis Books.

[31] Vaill, P. (1996). Learning as a way of being. San Francisco: JosseyBass.

[32] Yuchtman, E. \& Seashore, S. (1967), "Factorial Analysis of Organizational

[33] Performance", Administrative Science Quarterly 12(3), pp. 377-9 